Article

\title{
Biogenic Amines in Traditional Fiore Sardo PDO Sheep Cheese: Assessment, Validation and Application of a RP-HPLC-DAD-UV Method
}

\author{
Claudia Zazzu 1, Margherita Addis 2, Marco Caredda 2, Maria Francesca Scintu 2, \\ Giovanni Piredda ${ }^{2}$ and Gavino Sanna ${ }^{1, *}$ \\ 1 Dipartimento di Chimica e Farmacia, Università degli Studi di Sassari, via Vienna 2 - 07100 Sassari; \\ claudiazazzu@yahoo.it \\ 2 Agris Sardegna, Loc. Bonassai Km.18,600,- 07040 Olmedo (SS); maddis@agrisricerca.it (M.A.); \\ caredda.m@gmail.com (M.C.); mfscintu@agrisricerca.it; (M.F.S.); gpiredda@agrisricerca.it (G.P.) \\ * Correspondence: sanna@uniss.it; Tel.: +39-079-229500
}

\begin{abstract}
This contribution is aimed to measure for the first time the amount of biogenic amines (BAs) in one of the most ancient and traditional sheep cheese produced in Sardinia, Italy: the Protected Designation of Origin (PDO) Fiore Sardo. For doing this, an original RP-HPLC-DAD-UV method has been developed, completely validated in terms of LoD, LoQ, linearity, precision and trueness, and tested on 36 real Fiore Sardo PDO cheese samples produced by four different cheesemakers and marketed by four stores. The average total concentration of the eight BAs (i.e. tyramine, tryptamine, histidine, putrescine, cadaverine, 2-phenylethylamine, spermine and spermidine) measured in Fiore Sardo cheese was $700 \mathrm{mg} / \mathrm{kg}$, with a range between $170 \mathrm{mg} / \mathrm{kg}$ and $1100 \mathrm{mg} / \mathrm{kg}$. A great variability in the total amount of BAs has been evidenced among the Fiore Sardo marketed in the four stores as well as for the cheeses purchased in different times in the same store. Tyramine $(350 \mathrm{mg} / \mathrm{kg})$, putrescine $(150 \mathrm{mg} / \mathrm{kg})$, histamine $(80 \mathrm{mg} / \mathrm{kg})$ and cadaverine $(30$ $\mathrm{mg} / \mathrm{kg}$ ) are the most abundant BAs found in this matrix. Among many factors concurring, the dominant microflora of Fiore Sardo PDO is likely the principal cause of the qualitative and quantitative distribution of BAs in this matrix. Finally, the total amount of BAs found in Fiore Sardo $\mathrm{PDO}$ is not able to cause any situation of health alert for consumers.
\end{abstract}

Keywords: Fiore Sardo PDO; biogenic amines; sheep's cheese; RP-HPLC

\section{Introduction}

Biogenic amines (BAs) are organic bases characterized by a low molecular weight, a medium polarity and the presence of at least one aminic group bonded to an aliphatic, aromatic or heterocyclic moiety. BAs can be formed in food containing mainly proteins (or, simply, free amino acids) or also carbonylic compounds such as aldehydes or ketones. As a matter of fact, it is well known that the bacterial decarboxylation of amino acids or transamination of simple carbonylic compounds lead to the formation of BAs [1-3]. Many BAs show severe adverse effects towards human health: tyramine (Tyr) is cytotoxic, causing the necrosis of the HT29 intestinal cells, [4], again Tyr, tryptamine (Trp) and 2-phenylethylamine (Phe) are vasoactive [5], whereas histamine (His), putrescine (Put) and cadaverine (Cad) are toxic towards the nervous system [5]. The contemporary presence of Put and Cad in food potentiate the toxic action of His [6]. In addition, it has been demonstrated that BAs are possible precursors for the formation of carcinogenic $\mathrm{N}$-nitroso species [7]. Finally, the polyamines spermine (Spm) and spermidine (Spd) are often naturally present in food [8]. However, also their excess has been recently associated with potential health risks $[9,10]$. Despite their recognized toxicity, the limit concentrations of BAs in fermented foodstuffs are far to be adequately standardized by regulatory agencies. 
Among the foodstuffs prone to contain meaningful amounts of BAs, it is worth to remember dairy products [2,7,8,11-14], fish [15-17] and fish products [18,19], meat [20,21] and meat products [20-22], soy derivatives [6], fresh and fermented products by vegetables [23-25], chocolate [25], honey [1] and fermented beverages like wine [1,26-30] or beer [29,31].

As a matter of fact, cheese and - mainly - aged cheese provides an excellent substrate for the production of BAs [32-36]. The constant presence of both a not sterile environment and casein proteolysis during all cheese making activities ensures the constant availability of free amino acids. Furthermore, the profile and the concentration of BAs in cheese is associated with a number of technological factors: the use of raw (or pasteurized) milk [37-39], the presence of native (or inoculated by a starter culture) bacteria belonging to Pseudomonas, Enterobacter, Micrococcus, Lactobacillus, Leuconostoc, Lactococcus, and Streptococcus genera [35,40], the $\mathrm{pH}[35,41]$, the amount of $\mathrm{NaCl}$ added during the cheese making phases [35,41], but also the ripening [38,42], storage conditions $[32,41,43]$ and post-ripening technological processes (e.g. cutting, slicing, grating) $[44,45]$ play a key role in determining the amount of these compounds. All these variables concur to justify the enormous differences observed in the amount of the most common BAs at varying of the type of cheese. Although it should be possible to find cheeses in which the most common BAs are very low in concentration (also below the $\mathrm{mg} / \mathrm{kg}$ level) [46,47], it is quite normal measuring, for each of them, concentration levels in cheeses ranging between some tens of $\mathrm{mg} / \mathrm{kg}$, but it is not rare that the amounts found can also exceed the levels of hundreds [47-50] or even the level of thousands [46,51,52] of $\mathrm{mg} / \mathrm{kg}$ for His [46], Tyr [51,52], Put [46] and Cad [51]. Details of the different analytical approaches used for determining BAs in cheese have been extensively discussed in a number of excellent reviews on this topic $[6,32,33,36,53,54]$. Among others, liquid chromatography represents still nowadays the most preferred analytical choice $[7,8,12,40,42,46,55,56]$, even sometimes coupled with a mass spectrometry detection $[11,57,58]$. Other chromatographic methods have also been used for this aim, like ion-exchange chromatography [52,59], ion chromatography [60] gas-chromatography coupled with mass spectrometry [61]. Apart from chromatography, several analytical techniques can also be succesfully applied for measuring selected BAs: controlled-potential methods [22], enzyme-linked immunosorbent assay methods [62] and capillary electrophoresis techniques [63] have been proposed for the His determination, whereas amperometric biosensors were used for the determination of Tyr [64] and square wave adsorbpitive stripping voltammetry for the determination of $\operatorname{Trp}$ [65].

Traditional Fiore Sardo PDO (henceforward called simply "Fiore Sardo") is an uncooked and long-ripening hard cheese, produced only from raw whole milk by Sarda breed sheep. Its cheese making technique, unchanged for centuries, makes it the most ancient sheep cheese produced in Sardinia. The coagulation process of sheep milk is promoted by lamb or kid rennet paste, and this induces, during the ripening of the cheese, an intense lipolysis [66,67], whereas proteolysis is meaningful only in the first months of the ripening [68]. By a microbiological viewpoint, the mesophilic lactic acid bacteria (Lactococcus lactis) and enterococci (Enterococcus faecium) dominates the microflora of Fiore Sardo cheese [69-72]. The concomitant total absence of any thermal treatment underwent by the sheep's milk and the long ripening of Fiore Sardo cheese before marketing, makes feasible that the amount of BAs in the final product may be worthy of some attention.

At the best of our knowledge, no previous study was until now addressed to establish the presence of BAs in this cheese, whereas only one contribution has been published containing data on the amounts of BAs in other sheep's cheeses from Sardinia [73] but, unfortunately, the validation part of the analytical method is missing. For this reason, and on the basis of the previous results that our research group has achieved in last years in the assessment, validation and application of new methods for the determination of analytes of specific interest in sheep cheeses $[66,68,74-76]$, the principal aim of this study is to develop and validate an original RP-HPLC method devoted to the determination of eight BAs (i.e. Tyr, Trp, His, Put, Cad, Phe, Spm, Spd, all reported in Figure 1) in Fiore Sardo sheep's cheese. 
<smiles>NCCc1c[nH]cn1</smiles>

Histamine (His)

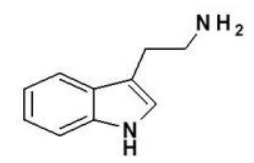

Tryptamine (Trp)

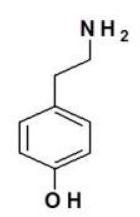

Tyramine (Tyr)

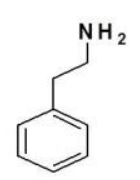

2-phenyl-ethylamine (Phe)

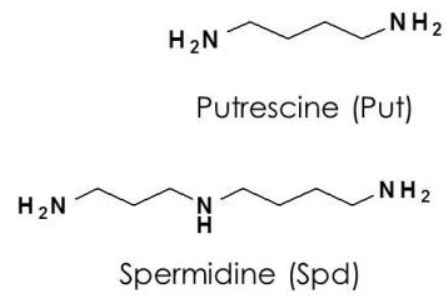

Cadaverine (Cad)

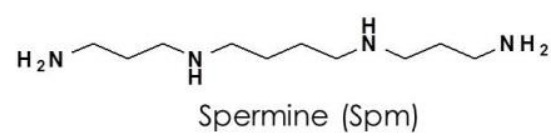

Figure 1. The eight BAs object of study.

\section{Materials and Methods}

\subsection{Sampling}

A total of 36 Fiore Sardo cheese samples (400 g ca. each), produced by four artisanal cheesemakers, were purchased in four different stores located in Italy. Each store was always supplied by the same cheesemaker. In order to give account for the intrinsic variability of samples produced by each cheesemaker, three samples were taken from each store every 15 days. Hence, a total of nine samples per store was collected. Samples were carried to the laboratory at $4{ }^{\circ} \mathrm{C}$ and stored at the same temperature until analysis.

\subsection{Chemicals}

Tyr (99\%), Trp (99\%), His (>99\%), Put (>99\%), Cad (>99\%), Phe (99\%), Spm (>99.5\%), Spd (99.5\%), 1,7-diaminoheptane $(>98.0 \%)$ and 5-(dimethylamino)-naphthalene-1-sulfonyl chloride $(>99.0 \%)$ were from Sigma-Aldrich (Milan, Italy). All BAs, except for 1,7-diaminoheptane, were purchased as hydrochloride salts, and the amounts weighted were corrected on the basis of their purity and referred to the free amine. $0.1 \mathrm{~mol} / \mathrm{L}$ aqueous solution of hydrochloric acid, $28 \%$ aqueous solution of ammonia, diethyl ether and sodium bicarbonate were analytical grade reagents from Carlo Erba (Milan, Italy), whereas HPLC grade acetonitrile was from Merck (Milan, Italy). Ultrapure (Type 1) water (specific resistance $>18 \mathrm{M} \Omega$ ) was always used throughout the analyses.

\subsection{Equipment}

The chromatographic apparatus used in this study was an Agilent Series 1100 HPLC (Agilent Technologies, Palo Alto, USA) equipped with a Guard-RP, HI-5RP-10C5/K pre-column (Agilent Technologies) a Kromasil 100-5 C18, $250 \mathrm{~mm}$ x $4.6 \mathrm{~mm}$ x $5 \mu \mathrm{m}$ particle size column (CPS Analitica, Milan, Italy) and a Diode Array Detector model DAD G 1315B (Agilent Technologies).

\subsection{Biogenic Amine Analysis}

\subsubsection{Exctraction and Derivatisation}

Cheese $(2 \mathrm{~g})$ was homogenized in $20 \mathrm{~mL}$ of a solution containing the internal standard $(20 \mathrm{mg} / \mathrm{L}$ of 1,7-diaminoheptane in $0.1 \mathrm{~mol} / \mathrm{L} \mathrm{HCl}$ ) and centrifuged at $1780 \mathrm{xg}$ for $20 \mathrm{~min}$ at $4{ }^{\circ} \mathrm{C}$. Extraction was repeated with $20 \mathrm{~mL}$ of $0.1 \mathrm{~mol} / \mathrm{L} \mathrm{HCl}$. Combined extracts were made up to $50 \mathrm{~mL}$ with $0.1 \mathrm{~mol} / \mathrm{L}$ $\mathrm{HCl}$ and then filtered on Whatman 42 paper.

As proposed by Innocente et al. [12], derivatisation was achieved by mixing $1 \mathrm{~mL}$ of acid extract with $0.5 \mathrm{~mL}$ of saturated $\mathrm{NaHCO}_{3}$ solution and derivatising reagent (5-(dimethylamino)naphthalene-1-sulfonyl chloride, dansyl chloride, $\mathrm{DCl}$ ) solution (10 mg, dissolved in $1 \mathrm{~mL}$ of acetone). 
The mixture was left for $60 \mathrm{~min}$ at $40^{\circ} \mathrm{C}$. The residual $\mathrm{DCl}$ was removed by adding $200 \mu \mathrm{L}$ of $28 \%$ ammonia aqueous solution, vortexed for $1 \mathrm{~min}$ and allowed to react in the dark for $30 \mathrm{~min}$ at room temperature. The DC derivates of BAs were then extracted three times with $1 \mathrm{~mL}$ of diethyl ether [7]. The combined extracts were dried under air flow, the residue was re-dissolved in $1 \mathrm{~mL}$ of acetonitrile and filtered through a $0.22 \mu \mathrm{m}$ PTFE filter before analysis.

\subsubsection{HPLC Separation}

$10 \mu \mathrm{L}$ of the $\mathrm{DCl}$ derivatized BAs solution was injected in the HPLC apparatus. The column was termostated at $30{ }^{\circ} \mathrm{C}$ and flux was set at $0.8 \mathrm{~mL} / \mathrm{min}$. Elution solvents were acetonitrile and water. The elution program used in the analysis is shown in Table 1. All analytes were eluted within ca. 20 min, and each run was 35 min long.

Table 1. Elution program for the HPLC gradient separation of the biogenic amines DCl derivates.

\begin{tabular}{ccc}
\hline Time (min) & Acetonitrile (\%) & Water (\%) \\
\hline 0 & 65 & 35 \\
1 & 65 & 35 \\
10 & 80 & 20 \\
12 & 90 & 10 \\
16 & 100 & 0 \\
30 & 100 & 0 \\
Post run & & \\
30.1 & 65 & 30 \\
35 & 65 & 30 \\
\hline
\end{tabular}

\subsubsection{Wavelength optimization}

Literature findings suggested the detection of dansyl derivates of biogenic amine at $254 \mathrm{~nm}$ [12]. However, the analysis of DAD spectrum of dansyl derivates of all biogenic amines standards at 5 $\mu \mathrm{g} / \mathrm{mL}$ revealed for all analytes a maximum of absorbance at $218 \mathrm{~nm}$ (Figure 2). Figure 3 shows the chromatographic profile of dansyl derivates of biogenic amines standards at $5 \mathrm{mg} / \mathrm{L}$ detecting both at $\lambda=254 \mathrm{~nm}$ (Figure 3A) and at $\lambda=218 \mathrm{~nm}$ (Figure 3B). An higher signal-to-noise ratio was observed at the lower wavelength, hence the $218 \mathrm{~nm}$ wavelength was used in this study.

\subsubsection{Identification and Quantification of the Biogenic Amines}

The peaks of dansy derivates of BAs were identified by comparing retention times with those of standard solutions. Quantification was accomplished by internal calibration on different concentration levels in the relevant linearity interval of each analyte. A $1000 \mathrm{mg} / \mathrm{L}$ stock solution containing each of the biogenic amines was properly diluted to obtain working solutions at concentrations ranging between 50 and $0.1 \mathrm{mg} / \mathrm{L}$, in order to build a calibration curve ranging between 2,5 and $1250 \mathrm{mg} / \mathrm{kg}$ of cheese. A known amount of internal standard (1,7-diaminoheptane in $0.1 \mathrm{~mol} / \mathrm{L} \mathrm{HCl}$ ) has been added to each working solution, and the mixture has been firstly subdue to the derivatization step and, next, to the HPLC analysis, that has been performed for three times. Figure 4 report a typical chromatogram obtained by a sample of Fiore Sardo cheese.

Since an overestimation effect was substantiated in the quantification of biogenic amines in Castelmagno, Raschera and Toma cow cheeses from Piedmont, Italy [11], a comparison between analytical data from the proposed method and a multiple standard addition method was performed for all BAs in two different samples of Fiore Sardo cheese (i.e. the first from the A store, and the second from the $\mathrm{C}$ store). No significant differences between results obtained from both methods were found for all analytes (criteria: two-tail t-test, $\mathrm{p}=0.95$ ). 


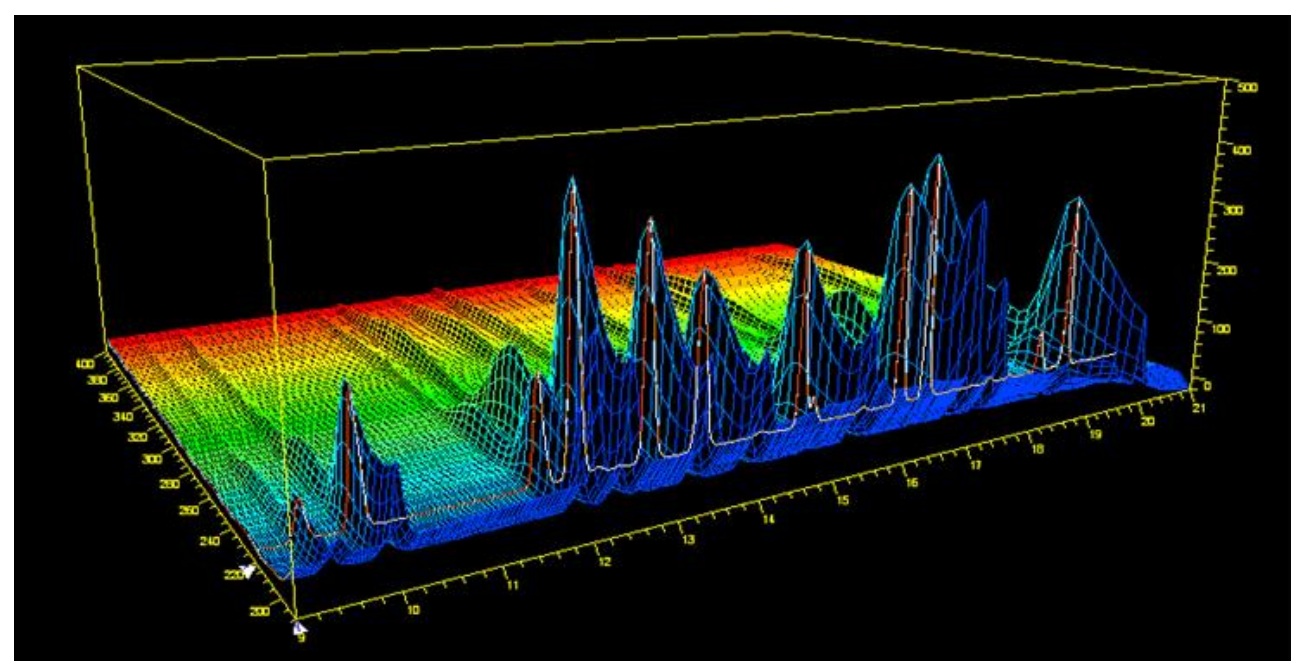

Figure 2. UV absorption of dansyl derivates of BA standard solutions (concentration: $5 \mathrm{mg} / \mathrm{L}$ each) as a function of the chromatographic run. $\lambda=218 \mathrm{~nm}$.
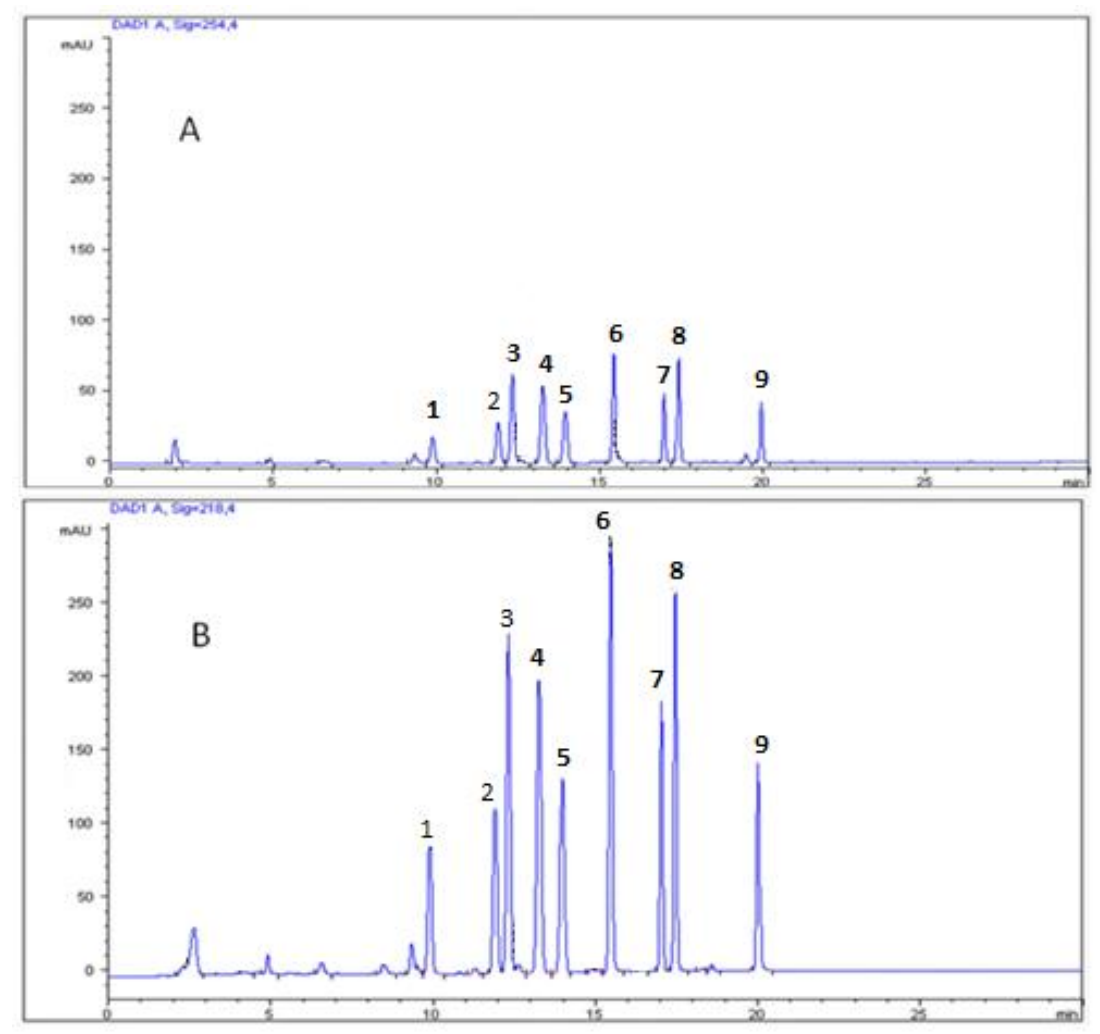

Figure 3. Chromatographic profile of dansyl derivates of standard solution (concentration: $5 \mathrm{mg} / \mathrm{L}$ each) of BAs. A, $\lambda=254 \mathrm{~nm}$; B, $\lambda=218 \mathrm{~nm}$. Peak sequence: $1=$ Trp; $2=$ Phe; $3=$ Put; $4=$ Cad; $5=$ His; $6=1,7$ diaminoheptane, internal standard; $7=$ Tyr; $8=$ Spd; $9=$ Spm. 


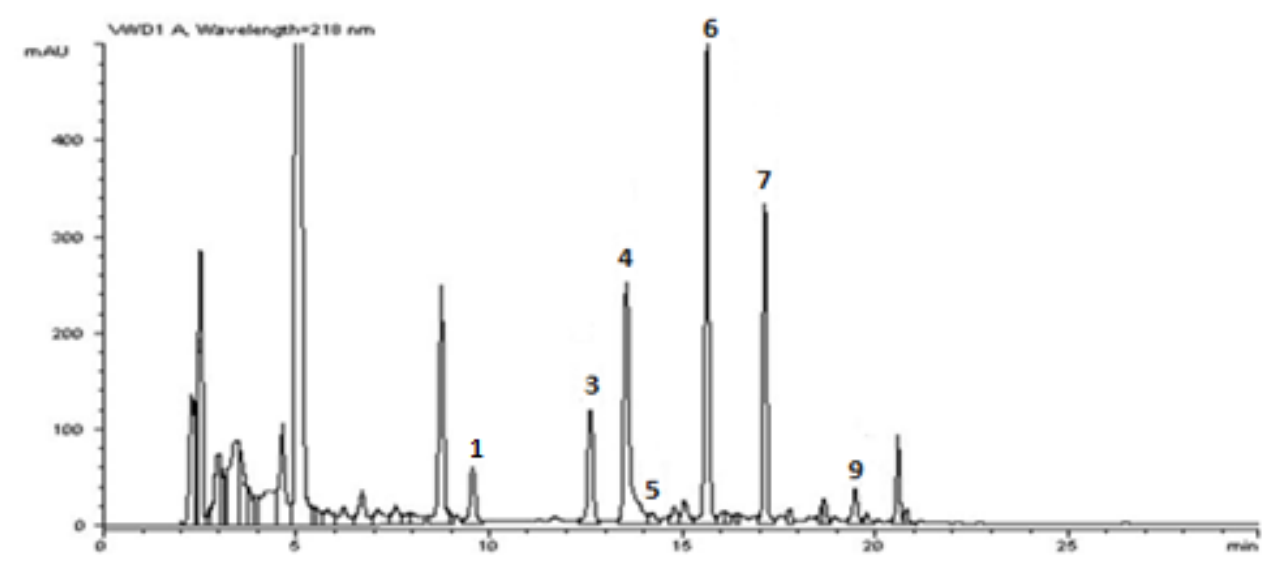

Figure 4. HPLC profile of the biogenic amines contained in a sample of Fiore Sardo cheese (D store). Peak sequence: $1=$ Trp; $3=$ Put, 4=Cad, 5=His, 6==1,7-diaminoheptane, internal standard, 7=Tyr, 9=Spm.

\subsubsection{Analytical method validation}

Validation of the proposed method was accomplished on the basis of limit of detection (LoD), limit of quantification (LoQ), linearity, precision and trueness. LoD was calculated according to the Upper Limit Approach (ULA1) approved by IUPAC [78]. For each biogenic amine, four different solutions at increasing concentrations close to the expected $\operatorname{LoD}$ (i.e., between 0.01 and $0.50 \mathrm{mg} \mathrm{L}^{-1}$ for each analyte) were prepared and analyzed. Each measurement was performed in triplicate. In addition, the ULA1 approach recommends that the LoQ value is three times the relevant LoD value. Linearity was checked on at least two orders of magnitude of concentration, as a function of the relative abundance of each biogenic amine in the range $0.1-50 \mathrm{mg} / \mathrm{L}$ (i.e. $2.5-1250 \mathrm{mg} / \mathrm{kg}$ of cheese). Precision was evaluated in terms of both repeatability (i.e. the CV measured for ten consecutive replicates of the same sample in the same analytical session) and intermediate precision (i.e., the $\mathrm{CV}$ obtained for the analysis of aliquots of the same sample by four different operators in different analytical sessions). The acceptability of these precision scores was checked in terms of HorRat ratio values (i.e., the ratio between experimental and theoretical CV measured on the basis of the Horwitz's theory) [79]. Due to the lack of any certified reference materials, trueness was estimated through recovery tests. Four aliquots of a Fiore Sardo cheese sample were submitted to the overall analytical procedure after the addition of increasing amounts of each BA to three of them, whereas the fourth was analyzed as it is (i.e. without any addition of BA). For each analyte, a plot of the analytical concentration, $C_{\exp , \mathrm{n}}(0 \leq \mathrm{n} \leq 3)$ measured after each addition of analyte (y axis) versus the $\mathbf{q}_{\mathrm{i}} / \mathbf{m}_{\mathbf{i}}$ ratio ( $x$ axis), where $q_{i}$ is the mass of the $i$-th addition of analyte $(1 \leq i \leq 3)$ and $\mathbf{m}_{i}$ is the mass of the $i$-th sample of cheese, was accomplished. The recovery is represented by the percent slope value of the regression line in this way obtained. The estimation of bias was made in triplicate. The presence/absence of bias has been evaluated by means of a two-tail $t$-test $(p=0.95)$.

\subsection{Statistical analysis}

The statistical package Minitab 16 (Minitab 16 Statistical Software (2010), State College, PA: Minitab, Inc.) was used for the statistical analysis. GLM (general linear model) analysis and Tukey test for multiple comparison of means were used for comparing cheeses purchased at different stores. The model included the effects of store/cheesemaker (F, 4 levels: A, B, C, D).

\section{Results and discussion}

\subsection{Assessment of the chromatographic method}

BAs determination is still nowadays one of the more demanding challenges in the field of the food analysis, and this is due by a number of factors. Firstly, the high polarity and the quite low 
molecular weight of the BAs favors their solubility in water rather than in the organic solvents commonly used for extraction by a matrix which nature may be also very complex. In addition, the contemporary presence in it of many analytes in a concentration range wide more than six orders of magnitude (typically between the $\mathrm{g} / \mathrm{kg}$ and the $\mu \mathrm{g} / \mathrm{kg}$ ), the absence of intrinsic properties that may facilitate their detection with both spectroscopic or electrochemical methods, and the presence of a number of potential interfering species makes this determination a very intriguing, but extremely complex analytical task. An extraction step is undoubtly needed in order to separate the BAs by potential interfering substances and increase the concentration of analytes in the extracts, but very often this shrewdness is not sufficient to ensure values of LoQ low enough to quantify also traces of BAs. Hence, also an additional step of derivatization of the analytes is frequently required. Unfortunately, both extraction and derivatization steps complicate the analytical method and may be responsible of also meaningful losses of analytes. In the specific case of cheese, the extraction of BAs has been accomplished by repeated treatment of the grated sample with aliquots of $0.1 \mathrm{~mol} / \mathrm{L}$ aqueous solution of $\mathrm{HCl}$, which proved in the past to be a very good choice for the extraction of biogenic amines from this matrix [55]. The approach chosen for developing the proposed method is the direct derivatization of the acidic extracts [12]. It represents a very convenient option in order to maximize the accuracy of the method reducing at the same time the lenght of the analysis and avoiding the unnecessary dilution of samples. Derivatization of BAs reduce the polarity of the analytes and improve their separation in RP columns. The most frequently used derivatizing agents adopted for BAs in cheese are the O-phthalaldehyde and - mainly - the dansyl chloride, and each of them is characterized by a number of advantages and drawbacks. One of the key advantages of Ophthalaldehyde is its rapid reaction with BAs also at room temperature. These derivatives are fluorescent, and this allow the reaching of very low LoD values (up to fmol levels). On the other hand, the principal drawback of the O-phthalaldehyde derivatives with BAs is a rather poor stability, mainly in comparison to the dansyl derivatives. Furthermore, the analytical column used for their separation have to be resistant to alkaline mediums. For these reasons, the most common reagent used in the last years in the derivatization of foods containing high amounts of BAs is the dansyl chloride. It provides stable derivatives that can be easily detected by a UV, DAD, fluorescence or MS detector, as a function of the expected concentration of BAs in the matrix considered. In addition, dansylation can be directly accomplished on the acidic extract of the cheese matrix [12], and this improve the overall accuracy of the method. The most meaningful drawback consists in the slowness of the reaction: the dansylation reaction is not quantitative at $20^{\circ} \mathrm{C}$, at $40^{\circ} \mathrm{C}$ it takes usually $60 \mathrm{~min}$ to accomplish the completeness, but the reaction time can be further reduced heating the reagents until $70{ }^{\circ} \mathrm{C}$. For these reasons, direct derivatization of the acidic extracts of cheese with dansyl chloride was the technique chosen for the proposed method. The nature of the cheese matrix, presumably rich in free amino acids, have suggested to insert, before chromatographic analysis, an extraction step with diethyl ether, aimed to separate the dansylated free amino acid (solubilized in the aqueous layer) from the dansyl derivatives of BAs, more affine to the organic layer [12]. The abundant literature relative to the RP-HPLC evaluation of BAs in cheeses of different origin offer many analytical insights in order to optimize the principal features of the RP-HPLC method. Reviews and articles covering this topic show that the C18 columns are the most used for this task. Among others, Hypersil BDS C18 [54] and Kromasil 100-5 C18 columns [12,24] are frequently adopted for cheese analysis. The comparative evaluation of the performance of both columns substantiated a worse resolution and an almost double duration of the chromatographic run for the Hypersil BDS C18 compared for the Kromasil 100-5 C18 column. For these reasons, this last column has been chosen for developing the proposed method. Finally, the optimization of the gradient of water and acetonitrile (i.e. the most preferred solvents previously used for this aim $[12,24,80,81,92]$ ) proposed by Torracca et al. [80] completed the chromatographic method developed in this study. 


\subsection{Validation parameters}

Table 2 shows the results obtained on the validation of the proposed method.

Table 2. Data obtained in the validation of the HPLC method for the biogenic amines analysis.

\begin{tabular}{|c|c|c|c|c|c|c|}
\hline \multirow[b]{2}{*}{ Analyte } & \multirow[b]{2}{*}{$\begin{array}{c}\text { LoD } \\
(\mathrm{mg} / \mathrm{kg})\end{array}$} & \multirow[b]{2}{*}{$\begin{array}{c}\text { LoQ } \\
(\mathrm{mg} / \mathrm{kg})\end{array}$} & \multicolumn{2}{|l|}{ Linearity } & Precision & \multirow{2}{*}{$\begin{array}{c}\text { Trueness } \\
\text { Recovery } \\
(\% \pm \text { SD) }\end{array}$} \\
\hline & & & $\begin{array}{c}\text { Linearity range, } \\
\mathrm{mg} / \mathrm{kg},\left(\mathbf{R}^{2}\right)\end{array}$ & $\begin{array}{c}\text { Repeatability } \\
\text { CV\% exper(r) } \\
\text { (HorRatr) }\end{array}$ & $\begin{array}{c}\text { Intermediate precision } \\
\text { CV\% exper(IP) } \\
\text { (HorRatIP) }\end{array}$ & \\
\hline Trp & 0.20 & 0.60 & $\begin{array}{l}0.75-100(0.9998) \\
2.5-1250(0.9993)\end{array}$ & $6.5(0.4)$ & $14.3(0.9)$ & $99 \pm 2$ \\
\hline Phe & 0.10 & 0.30 & $\begin{array}{c}0.5-125(0.9998) \\
2.5-1250(0.9996)\end{array}$ & $6.8(0.4)$ & $10.7(0.7)$ & $94 \pm 2$ \\
\hline Put & 0.07 & 0.20 & $2.5-1250(0.9905)$ & $4.4(0.3)$ & $7.0(0.4)$ & $87 \pm 9$ \\
\hline Cad & 0.13 & 0.40 & $\begin{array}{c}0.5-250(0.9999) \\
2.5-1250(0.9949)\end{array}$ & $4.1(0.3)$ & $6.4(0.4)$ & $95 \pm 12$ \\
\hline His & 0.20 & 0.60 & $\begin{array}{l}0.75-500(0.9997) \\
2.5-1250(0.9994)\end{array}$ & $3.8(0.2)$ & $9.2(0.6)$ & $85 \pm 5$ \\
\hline Tyr & 0.17 & 0.50 & $2.5-1250(0.9979)$ & $5.0(0.3)$ & $4.9(0.3)$ & $90 \pm 6$ \\
\hline Spd & 0.23 & 0.70 & $2.5-1250(0.9945)$ & - & - & - \\
\hline Spm & 0.07 & 0.20 & $\begin{array}{l}0.25-100(0.9999) \\
2.5-1250(0.9949)\end{array}$ & $8.6(0.5)$ & $16.1(1.0)$ & $82 \pm 8$ \\
\hline
\end{tabular}

LoD and LoQ values lie in the range between $0.07 \mathrm{mg} / \mathrm{kg}$ and $0.23 \mathrm{mg} / \mathrm{kg}$ and between 0.20 $\mathrm{mg} / \mathrm{kg}$ and $0.70 \mathrm{mg} / \mathrm{kg}$, respectively. Data are consistent with those already published [54,81]. In principle, linearity was evaluated along more than two orders of magnitude of concentration, ranging between $2.5 \mathrm{mg} / \mathrm{kg}$ and $1250 \mathrm{mg} / \mathrm{kg}$. However, a preliminary evaluation of the samples revealed that the concentration levels expected for some biogenic amines in some Fiore Sardo samples (i.e. Trp, Phe, Cad, His and Spm) were below the lowest concentration value considered in the linearity interval. Therefore a second calibration curve was taken into account for those analytes, where the least concentration was only slightly higher than the relevant LoQ, obtaining in this case $\mathrm{R}^{2}$ values between 0.9997 and 0.9999 . Consequently, linearity is only sufficient for Put, acceptable for Spd, Cad (2.5-1250 $\mathrm{mg} / \mathrm{kg}$ range) and Spm (2.5-1250 mg/kg range), good for Tyr and excellent for the remaining analytes/concentration range couples. Precision data are between $3.8 \%$ (His) and $8.6 \%$ (Spm) for repeatability, and between $4.9 \%$ (Tyr) and $16.1 \%(\mathrm{Spm})$ for the intermediate precision measurement. All of them can be considered acceptable for the concentration range considered according the Horwitz's theory [79], as proved by the relevant HorRat ratios, always below the threshold value of 1.5. Finally, the amounts of the recovery values measured in this study are in good agreement with those already reported in literature $[12,54,55,81]$. The two tail $t$-test $(p=0.95)$ substantiates that all values obtained are not statistically different from the quantitative recovery ( $t_{\text {exp }}$ between 0.71 , Trp, and 4.24, Phe and His, tab $=4.30$ ), hence accounting for a general absence of bias of the method proposed.

\subsection{Biogenic Amines in Fiore Sardo Sheep Cheese}

The proposed analytical method was used to determine the biogenic amine content in 36 Fiore Sardo cheese samples, produced by four cheesemakers and purchased in four diffent stores. The results obtained are shown in Table 3, in which the mean value of the nine samples of every local store/cheesemaker, the standard deviation of their distribution and their range are indicated for each biogenic amine. 
The average total concentration of the eight BAs measured in Fiore Sardo cheese is $700 \mathrm{mg} / \mathrm{kg}$. The great variability in the total amount of BAs, evidenced by the wide range (between the $170 \mathrm{mg} / \mathrm{kg}$ for the Fiore Sardo samples purchased in store A and the $1100 \mathrm{mg} / \mathrm{kg}$ for the cheeses purchased in store $\mathrm{C}$ ) is reflected also in the very high variability in BAs concentration found for the cheeses purchased in different times in the same store. Also the concentration of each BA measured in Fiore Sardo cheese is extremely variable among the different stores. Spm is the most abundant BA in Fiore Sardo purchased in store A and its content is significantly higher respect to that determined in cheeses purchased in the other stores $(\mathrm{p}<0.001)$. In cheeses $\mathrm{A}$, Spm is followed by Tyr, whereas the remaining BAs show average concentrations less than $10 \mathrm{mg} / \mathrm{kg}$ each. On the other hand, Tyr is the most abundant BA in Fiore Sardo purchased in the remaining stores (mainly for store $\mathrm{C}, \mathrm{p}<0.001$ ), followed by Put (mainly for store $B, p<0.001$ )) and His (mainly for store $C, p<0.001$ )). Spm and Cad are constanty present in these matrices at average levels of few tens of $\mathrm{mg} / \mathrm{kg}$, whereas still less abundant are Phe and Trp. Finally, Spd was always found to be below its LoD. The remarkable differences among producers in the application of a cheese making process that is still today almost artisanal and - mainly - the differences in the technique of preparation and use of the rennet paste are likely responsible of the extremely wide dispersion of data measured for each BA in this study.

For the reader's convenience, Table 4 summarizes the results of the determination of BAs in a wide number of sheep's cheeses produced worldwide. In particular, literature reported data obtained also on different sheep's cheeses produced in Sardinia [73]. The results here obtained are in good agreement with those reported in such study for the Pecorino cheese produced from farmhouses. As well as for the Fiore Sardo, also this cheese is made from raw milk, coagulated without the presence of any starter culture, and its ripening takes place in rooms with no control over humidity or temperature. On the other hand, the farmhouse Pecorino is a semicooked cheese that is coagulated with calf rennet (and not with lamb or kid rennet, like happens for Fiore Sardo cheese). On the other hand, results obtained in this study are not too different from those obtained for Feta (Valsamaki et al., 2000) [82] and for some sheep's cheese produced in different Regions of Italy (Abruzzo, Schirone et al., 2013 [91] and Tuscany, Torracca et al, 2015 [92]). However, it is interesting to note that the Feta is not a pure sheep cheese, because it is obtained by a mixture of sheep and goat milk, and also the sheep's cheese from Tuscany and Abruzzo are often obtained adopting other technological procedures (i.e. the milk has been undergone to thermal treatments, a starter culture has been used, there are differences on the nature of the rennet and of the ripening technique). On the basis of the data obtained, it is possible to think that the total BAs amount found in Fiore Sardo is relatively low also in comparison to other sheep's cheeses [88,91], and surely not able to determine any significant situation of health alert for consumers.

However, the comparative exam of BAs amounts measured on the sheep's cheeses reported in Table 4 allowed to indicate at least two general trends: i) in many sheep's cheeses Tyr was very often the most abundant BA and ii) also Put and Cad were frequently found in high concentrations. The principal microbial groups found in sheep's cheeses are mesophilic and thermophilic lactobacilli, streptococci and enterococci, all within the range $10^{5}-10^{7} \mathrm{cfu} / \mathrm{g}$. In particular, the dominant microflora of Fiore Sardo is constituted by lactococci, always associated with a minor amount of enterococci $[67,69,93]$. Both micro-organisms remain also during the ripening of the cheese, and they are likely responsible of the high amounts always measured for Tyr, whereas the enterococci strains, able to decarboxylize aminoacids [94], may be responsible not only to the accumulation of $\alpha, \omega-$ diamines like Put and Cad, but also of meaningful amounts of His [95]. Obviously, a number of additional parameters like the nature and the technique of preparation of the rennet, the water activity, the $\mathrm{pH}$, the $\mathrm{NaCl}$ concentration, the conditions of storage and the time and the temperature of ripening, all still not strictly codificated by the specification of the Fiore Sardo sheep cheese, surely play a role in defining the extreme variability of the distribution of the BAs in this ancient and unique cheese from Sardinia.

\section{Conclusion}


For the first time, the concentration of eight biogenic amines (i.e. Tyr, Trp, His, Put, Cad, Phe, Spm, Spd) has been measured on a reliable sampling of the most ancient raw sheep cheese produced in Sardinia, Italy: the traditional Fiore Sardo. For do this, a new RP-HPLC-DAD-UV method has been developed, validated and tested on 36 real samples produced by four different cheesemakers and marketed by four stores. Validation was accomplished on the basis of limit of detection, limit of quantification, linearity, precision and trueness. Quantification limits have been always below 0.75 $\mathrm{mg} / \mathrm{kg}$, linearity, measured always on a range of at least two orders of magnitude of concentration, has been sufficient for Put, but is excellent for more of the half of the analytes and concentration ranges considered. The evaluation of precision and trueness gave account for the overall accuracy of the method proposed. The average amount of the sum of the eight biogenic amines measured in Fiore Sardo sheep cheese is $700 \mathrm{mg} / \mathrm{kg}$, whereas the range is between $170 \mathrm{mg} / \mathrm{kg}$ and $1100 \mathrm{mg} / \mathrm{kg}$. If compared with much more higher amounts often reported in literature, these concentrations seem not able to justify any situation of health alert for potential consumers. In order of decreasing concentration, Tyr, Put, His and Cad have been the most abundant analytes measured in this matrix, with average concentrations of $350 \mathrm{mg} / \mathrm{kg}, 150 \mathrm{mg} / \mathrm{kg}, 80 \mathrm{mg} / \mathrm{kg}$ and $30 \mathrm{mg} / \mathrm{kg}$, respectively, whereas Spd was always found below its LoD. The amount of each biogenic amine varied greatly not only among different stores (and, hence, among different producers), but also among different samples provided in different times by the same producer to the same store. Beyond the dominant microflora (mesophilic and thermophilic lactobacilli, streptococci and enterococci) characterizing the raw sheep milk and - consequently - the Fiore Sardo cheese, it is likely that such very wide variability in the amount of BAs depends also by a number of technological parameters, like the nature and the technique of preparation of the rennet, the water activity, the $\mathrm{pH}$, the $\mathrm{NaCl}$ concentration, the conditions of storage and the time and the temperature of ripening, all being still not strictly codificated by the specification of the Fiore Sardo sheep cheese. 
Table 3. Mean amount $( \pm \mathrm{sd})$ and range of biogenic amine content in Fiore Sardo cheese samples. Data are expressed in $\mathrm{mg} / \mathrm{kg}$ of cheese.

\begin{tabular}{|c|c|c|c|c|c|c|c|c|c|c|c|c|c|c|c|}
\hline \multirow[t]{2}{*}{ Stores } & \multicolumn{2}{|c|}{$\operatorname{Trp}$} & \multicolumn{2}{|c|}{ Phe } & \multicolumn{2}{|c|}{ Put } & \multicolumn{2}{|c|}{ Cad } & \multicolumn{2}{|c|}{ His } & \multicolumn{2}{|c|}{ Tyr } & \multicolumn{2}{|c|}{ Spm } & \multirow{2}{*}{$\frac{\Sigma \text { BAs }}{\text { Mean } \pm \text { sd }}$} \\
\hline & Mean \pm sd & range & Mean \pm sd & range & Mean \pm sd & range & Mean \pm sd & range & Mean \pm sd & range & Mean \pm sd & range & Mean \pm sd & range & \\
\hline A & $0.4 \pm 0.4$ & $<0.2-1.2$ & $2^{\mathrm{b}} \pm 2$ & $<0.3-6.3$ & \multicolumn{2}{|c|}{$<0.2^{c}$} & $6^{\mathrm{b}} \pm 4$ & $1.3-13$ & $4^{c} \pm 6$ & $<0.65-19$ & $60^{c} \pm 70$ & $<0.5-180$ & $100^{a} \pm 30$ & $8-160$ & $170 \pm 80$ \\
\hline B & $3 \pm 3$ & $0.2-8.2$ & $16^{\mathrm{a}} \pm 8$ & $1.8-25$ & $450^{a} \pm 200$ & $88-730$ & $20^{\mathrm{ab}} \pm 30$ & $1.0-94$ & $85^{\mathrm{b}} \pm 75$ & $5.2-250$ & $400^{\mathrm{b}} \pm 100$ & $170-530$ & $30^{\mathrm{b}} \pm 30$ & $30 \pm 30$ & $1000 \pm 200$ \\
\hline C & $4.4 \pm 3.5$ & $0.3-10.5$ & $15^{\mathrm{a}} \pm 10$ & $9.3-42$ & $130^{\mathrm{b}} \pm 70$ & $36-210$ & $40^{\mathrm{a}} \pm 20$ & $6.7-70$ & $210^{\mathrm{a}} \pm 20$ & $190-250$ & $700^{\mathrm{a}} \pm 100$ & $445-800$ & $30^{\mathrm{b}} \pm 30$ & $30 \pm 30$ & $1100 \pm 100$ \\
\hline $\mathrm{D}$ & $5.5 \pm 6.5$ & $<0.2 \quad-16.9$ & $9^{\mathrm{ab}} \pm 10$ & $1.3-27$ & $20^{\mathrm{bc}} \pm 20$ & $<0.2-49$ & $40^{\mathrm{a}} \pm 25$ & $7.3-83$ & $10^{c} \pm 10$ & $<0.65-33$ & $300^{\mathrm{b}} \pm 300$ & $110-770$ & $50^{\mathrm{b}} \pm 10$ & $50 \pm 10$ & $500 \pm 300$ \\
\hline Total & $3 \pm 8$ & $<0.2-16.9$ & $10 \pm 20$ & $<0.3-42$ & $150 \pm 200$ & $<0.2-730$ & $30 \pm 50$ & $1.0-94$ & $80 \pm 80$ & $<0.65-250$ & $350 \pm 300$ & $<0.5-800$ & $50 \pm 60$ & $8-160$ & $700 \pm 400$ \\
\hline re Effec & ns & & $* *$ & & $* * *$ & & * & & $* * *$ & & $* * *$ & & $* * *$ & & \\
\hline
\end{tabular}

Mean values and sd have been calculated on the basis of not-rounded analytical data. $\mathbf{\Sigma B A s}=$ Total mean BAs amount for each store. Amounts in italic character are below the

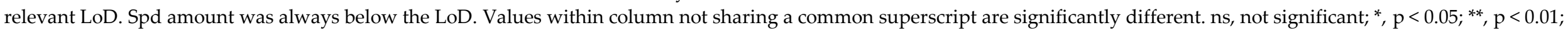
$* * *, \mathrm{p}<0.001$.

Table 4. Concentrations (mean and/or range) of selected biogenic amines in sheep cheeses. Data are expressed in $\mathrm{mg} / \mathrm{kg}$ of cheese.

\begin{tabular}{|c|c|c|c|c|c|c|c|c|c|c|}
\hline Sheep cheese & Key features & Trp & Phe & Put & Cad & His & Tyr & Spm & Spd & Reference \\
\hline Zamorano, Spain & $\begin{array}{l}\text { Cheese made from raw milk; } \\
\text { BAs have been measured } \\
\text { between } 1 \text { day and } 10 \\
\text { months of ripening. } \\
\text { Data are inferred by the } \\
\text { Figure } 8 \text { of the study. }\end{array}$ & $3-50$ & $3-120$ & $10-190$ & $5-35$ & $1-55$ & $1-85$ & $0-20$ & $0-115$ & 8 \\
\hline Azeitão cheese & $\begin{array}{l}\text { Cheese made from raw milk } \\
\text { using an exctract of Cardoon } \\
\text { as rennet. The length of } \\
\text { ripening is at least of } 20 \text { days. }\end{array}$ & NM & NM & ND - 137 & $161-260$ & $414-818$ & $72.3-445$ & $17.2-81.6$ & NM & 48 \\
\hline $\begin{array}{l}\text { Pecorino } \\
\text { Carmasciano, } \\
\text { Italy }\end{array}$ & $\begin{array}{l}\text { Cheese obtained from raw } \\
\text { milk, coagulated at } 40-45^{\circ} \mathrm{C} \\
\text { with lamb curdle and } \\
\text { ripened for } 201 \text { days. } \\
\text { Data are inferred by the } \\
\text { Figure } 4 \text { of the study. }\end{array}$ & NM & NM & 100 & 120 & 65.5 & 136.41 & 350 & 110 & 49 \\
\hline
\end{tabular}




\begin{tabular}{|c|c|}
\hline $\begin{array}{l}\text { Pecorino di } \\
\text { Farindola, Italy }\end{array}$ & $\begin{array}{l}\text { Cheese obtained from raw } \\
\text { milk, coagulated at } 30-35^{\circ} \mathrm{C} \\
\text { with pig rennet and ripened } \\
\text { for } 90 \text { days. }\end{array}$ \\
\hline $\begin{array}{l}\text { 1) Pecorino Sardo } \\
\text { PDO } \\
\text { 2) Pecorino } \\
\text { 3) Casu Marzu }\end{array}$ & $\begin{array}{l}\text { 1) Pecorino Sardo PDO is } \\
\text { semi-cooked cheese made } \\
\text { from thermised sheep milk } \\
\text { inoculated with a starter } \\
\text { culture and coagulated with } \\
\text { calf rennet, ripening time } \\
\text { between } 1 \text { and } 12 \text { months. } \\
\text { 2) Pecorino is semi-cooked } \\
\text { cheese made from raw sheep } \\
\text { milk without a starter culture } \\
\text { and coagulated with calf } \\
\text { rennet, ripening time } \\
\text { between } 2 \text { and } 12 \text { months. } \\
\text { 3) Casu Marzu is a sheep's } \\
\text { cheese produced with the } \\
\text { use of larvae of the cheese fly } \\
\text { Piophila casei. Ripened for } 2- \\
3 \text { months in warmer rooms. }\end{array}$ \\
\hline
\end{tabular}

Pecorino

Abruzzese, Italy

Two kinds of cheese:

a) raw milk, no starter culture;

b) Thermized milk with the addition of starter culture.

Ripening time: 60 days.

Data are inferred by the

Figure 2 of the study.

Feta, Greece

Cheese from thermized milk constituted by $70 \%$ of sheep milk and $30 \%$ of goat milk, ripened and stored in brine. BAs have been measured during 4 months after

$\begin{array}{cccccccc}1) & 1) & 1) & 1) & 1) & 1) & 1) & 1) \\ \mathrm{ND}-9.3 & \mathrm{ND} & 0.1-0.8 & 0.1-9.7 & \mathrm{ND}-7.2 & \mathrm{ND}-19.3 & \mathrm{ND}-7.2 & 0.2-5.4 \\ 2 \text { ) } & 2 \text { ) } & 2) & 2) & 2) & 2) & 2) & 2) \\ \mathrm{ND}-13.5 & \mathrm{ND}-8.6 & \mathrm{ND}-92.7 & \mathrm{ND}-137.0 & \mathrm{ND}-128.4 & 1.6-93.0 & \mathrm{ND} & \mathrm{ND} \\ 3 \text { ) } & 3) & 3) & 3) & 3) & 3) & 3) & 3) \\ \mathrm{ND}-41.8 & \mathrm{ND}-90.9 & 1.9-165.8 & 3.1-470.7 & \mathrm{ND}-126 & \mathrm{ND}-231.4 & \mathrm{ND} & \mathrm{ND}\end{array}$

$\begin{array}{ccc}\text { a) } & \text { a) } & \text { a) } \\ 25^{\mathrm{a} ;} & 40^{\mathrm{a}} ; & 60^{\mathrm{a}} ; \\ 0-50 & 35-45 & 40-80 \\ \text { b) } & \text { b) } & \text { b) } \\ 15^{\mathrm{a}} ; & 300^{\mathrm{a}} ; & 150^{\mathrm{a}} ; \\ 10-20 & 30-600 & 40-250\end{array}$

a)
$20^{\mathrm{a}} ;$
$10-35$
b)
$50^{\mathrm{a}} ;$
$0-120$

a)
$270^{\mathrm{a}}$
$130-3$

b)
60 ;
$30-100$

$4.39-5.74$

$3.51-4.94$ 
production

Manchego, Spain (refs. 83 and 85)

and Venezuela

ref. 84)

Cheese made from raw milk; BAs have been measured after 3 and 6 months of ripening

months:

$<$ LoD -2.8

6 months:

Commercial samples, no

details on the production

$53.78^{\mathrm{a}}$

phase

Cheese made from raw milk; BAs have been measured between 3 and 8 months of ripening

Pecorino, Italy

a) high pressure homogenization of raw milk b) raw milk,

c) thermized milk.

Ripening time: 21 days

Terrincho

Portugal

Cheese obtained from raw milk, coagulated with calf rennet and ripened for 30 days.

Formaggio di

fossa, Italy

1) Bryndza

2) Smoked cheese

3) Fresh cheese

4) Unripened

(fresh) cheese

5) Pasta filata type

cheese

6) Brined cheese
Sheep cheese characterized by a ripening performed into pits dug in the sandstone for 90 days

Cheeses $1-3$ were from raw ewe's milk, whereas cheeses $4-7$ were from pasteurized ewe's milk.<smiles>N#[W][W]</smiles>

\section{1) $\mathrm{ND}-60.9$}

2) $16.2-99.9$

3) $\mathrm{ND}-20.7$

4) ND -118.2

5) ND

6) ND - 229.5

7) $\mathrm{ND}-108.8$
2) $\mathrm{ND}-80.7$
3) ND -19.6
4) ND - 35.8
5) ND
6) ND - 125.6
7) $\mathrm{ND}$

1) ND -42.6

\section{3 months: \\ $24.5-50.3$ \\ 6 months: \\ 54.1 - 229}

98.93a

76.70-121.18

$60.0-100.1$

$109.4-326.8$

NM

NM

a) 62.8

b) 162

c) 350

a) 0

a) 3.35

c) 23.92

b) 1.49

a) 10.4

b) 9.03

c) 0

c) 15.9

$0.0-283.1$

NM

NM

461.62

0

16.49

2) ND

4) $\mathrm{ND}$

4) ND

5) ND

6) ND

(7)

2) $8.9-38.3$

1) ND - 9.7

5) ND

2) ND

3) $\mathrm{ND}$

5) $\mathrm{ND}-13.0$

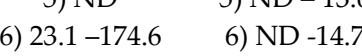

7) ND - 114.7
83 
7) Flavored cheese

\begin{tabular}{|c|c|c|c|c|c|c|c|c|c|c|}
\hline $\begin{array}{l}\text { Blue-veined } \\
\text { cheese }\end{array}$ & $\begin{array}{l}\text { Cheese made from } \\
\text { pasteurized } \\
\text { sheep's milk and ripened for } \\
6 \text { to } 12 \text { months }\end{array}$ & $61.88-71.11$ & $\begin{array}{c}13.25- \\
61.44\end{array}$ & $17.28-33.46$ & NM & NM & $7.15-52.20$ & NM & $\mathrm{NM}$ & 90 \\
\hline $\begin{array}{l}12 \text { cheeses from } \\
\text { Abruzzo, Italy }\end{array}$ & $\begin{array}{l}\text { 1) } 3 \text { cheeses were from } \\
\text { sheep's and cow's milk, } \\
\text { ripening time between } 3 \text { and } \\
8 \text { months. } \\
\text { 2) } 9 \text { cheeses were only from } \\
\text { sheep's milk, ripening time } \\
\text { between } 3 \text { and } 10 \text { months. }\end{array}$ & NM & $\begin{array}{c}1) \\
26.0-232.4 \\
2) \\
\mathrm{ND}-44.4\end{array}$ & $\begin{array}{c}1) \\
8.9-986.0 \\
2) \\
\mathrm{ND}-377.7\end{array}$ & $\begin{array}{c}1) \\
\mathrm{ND}-2172.6 \\
2) \\
\mathrm{ND}-116.4\end{array}$ & $\begin{array}{c}1) \\
200-743.3 \\
2) \\
10.3-761.4\end{array}$ & $\begin{array}{c}1) \\
312.1-1771.3 \\
2) \\
\mathrm{ND}-702.4\end{array}$ & NM & $\mathrm{NM}$ & 91 \\
\hline $\begin{array}{l}\text { Pecorino Toscano, } \\
\text { Italy }\end{array}$ & $\begin{array}{l}\text { Four kinds of sheep's } \\
\text { cheeses, different each } \\
\text { among other by the nature of } \\
\text { thermal treatment (two from } \\
\text { raw milk, two from } \\
\text { pasteurized milk), the nature } \\
\text { of the starter culture (two } \\
\text { different types), the weight } \\
\text { of the rind (between } 1 \text { and } 2.4 \\
\mathrm{~kg} \text { ) and the conditions and } \\
\text { the length of the ripening. }\end{array}$ & $11-88$ & $24-144$ & $22-512$ & $2-262$ & ND - 23 & $147-1132$ & ND - 2 & $\mathrm{ND}$ & 92 \\
\hline $\begin{array}{l}\text { Fiore Sardo } \\
\text { cheese, Italy }\end{array}$ & $\begin{array}{l}\text { Cheese produced from raw } \\
\text { milk, minimum ripening } \\
\text { time: } 3.5 \text { months }\end{array}$ & $\begin{array}{c}3 \mathrm{a} ; \\
<0.2-16.9\end{array}$ & $\begin{array}{c}10^{\mathrm{a}} ; \\
<0.3-42\end{array}$ & $\begin{array}{c}150^{\mathrm{a}} ; \\
<0.2-730\end{array}$ & $\begin{array}{c}30^{\mathrm{a}} \\
1.0-94\end{array}$ & $\begin{array}{c}80^{\mathrm{a}} ; \\
<0.65-250\end{array}$ & $\begin{array}{c}350^{\mathrm{a}} ; \\
<0.5-800\end{array}$ & $\begin{array}{c}50 \text { a; } \\
10-160\end{array}$ & $<0.23$ & This study \\
\hline
\end{tabular}


Author Contributions: M.A., G.S., M.F.S. and G.P. conceived and designed the experiments; C.Z. performed the experiments; M.A., G.S. and M.C. analyzed the data; M.A., M.C. and G.S. wrote the paper.

Funding: This research received no external funding.

Acknowledgments: The authors would like gratefully to thank the three anonymous reviewers for their helpful and valuable comments, that led a meaningful improvement of the work.

Conflicts of Interest: The authors declare no conflict of interest

\section{References}

1. Kelly, M.T.; Blaise, A.; Larroque, M. Rapid automated high performance liquid chromatography method for simultaneous determination of amino acids and biogenic amines in wine, fruit and honey, J. Chromatogr. A 2010, 1217, 7385-7392, DOI: 10.1016/j.chroma.2010.09.047.

2. Mayer, H.K.; Fiechter, G.; Fischer, E. A new ultra-pressure liquid chromatography method for the determination of biogenic amines in cheese, J. Chromatogr. A 2010, 1217, 3251-3257, DOI: 10.1016/j.chroma.2009.09.027.

3. Chong, C.Y.; Abu Bakar, F.; Russly, A.R.; Jamilah, B.; Mahyudin, N.A. The effects of food processing on biogenic amines formation, Int. Food Res. J. 2011, 18, 867-876.

4. Linares, D.M.; del Rio, B.; Redruello, B.; Ladero, V.; Martin, M.C.; Fernandez, M.; Ruas-Madiedo, P.; Alvarez, M.A. Comparative analysis of the in vitro cytotoxicity of the dietary biogenic amines tyramine and histamine. Food Chem 2016, 197 (Part A), 658-663, DOI: 10.1016/j.foodchem.2015.11.013.

5. McCabe, B.J.; Wolfe, J.J.; Frankel, E.H. Handbook of Food-Drug Interactions, Taylor \& Francis, 2003, ISBN 9780849315312.

6. Mohammed, G.I.; Bashammakh, A.S.; Alsibaai, A.A.; Alwael, H.; El-Shahawi. M.S. A critical overview on the chemistry, clean-up and recent advances in analysis of biogenic amines in foodstuffs. Trends Anal.Chem. 2016, 78, 84-94, DOI: 10.1016/j.trac.2016.02.007.

7. Vale, S.R.; Glória, M.B. Determination of biogenic amines in cheese. J AOAC Int 1997, 80, 1006-1012.

8. Combarros-Fuertes, P.; Fernandez, D.; Arenas, R.; Diezhandino, I.; Tornadijo, M.E.; Fresno, J.M. Biogenic amines in Zamorano cheese: factors involved in their accumulation. J Sci Food Agric 2016, 96, 295-305, DOI: 10.1002/jsfa.7093.

9. Ramani, D.; De Bandt, J.P.; Cynober. L. Aliphatic polyamines in physiology and diseases. Clin Nutr. 2014, 33(1), 14-22, DOI: 10.1016/j.clnu.2013.09.019.

10. Wang, C.; Ruan, P.; Zhao, Y.; Li, X.; Wang, J.; Wu, X.; Liu, T.; Wang, S.; Hou, J.; Li, W.; Li, Q.; Li, J.; Dai, F.; Fang, D.; Wang, C.; Xie. S. Spermidine/spermine N(1)-acetyltransferase regulates cell growth and metastasis via $\mathrm{AKT} / \beta$-catenin signaling pathways in hepatocellular and colorectal carcinoma cells. Oncotarget 2017, 8, 1092-1109, DOI: 10.18632/oncotarget.13582.

11. Gosetti, F.; Mazzucco, E.; Gianotti, V.; Polati, S.; Gennaro, M.C. High performance liquid chromatography/tandem mass spectrometry determination of biogenic amines in typical Piedmont cheeses, J. Chromatogr. A 2007,1149, 151-157, DOI: 10.1016/j.chroma.2007.02.097.

12. Innocente, N.; Biasutti, M.; Padovese, M.; Moret, S. Determination of biogenic amines in cheese using HPLC technique and direct derivatization of acid extract, Food Chem. 2007, 101, 1285-1289; DOI: 10.1016/j.foodchem.2005.12.026.

13. Linares, D.M.; Martin, M.M.; Ladero, V.; Alvarez, M.A.; Fernandez, M. Biogenic amines in dairy products, Crit. Rev. Food Sci. Nutr. 2011,51, 691-703; DOI: 10.1080/10408398.2011.582813.

14. Švarc-Gajic, J.; Stojanovic, Z. Determination of histamine in cheese by chronopotentiometry on a thin film mercury electrode, Food Chem. 2011,124, 1172-1176, DOI: 10.1016/j.foodchem.2010.07.030 .

15. Ruiz-Capillas, C.; Moral, A. Production of biogenic amines and their potential use as quality control indices for hake (Merluccius merluccius, L.) stored in ice, J. Food Sci. 2001, 66, 1030-1032, DOI: 10.1111/j.13652621.2001.tb08230.x.

16. Sagratini, G.; Fernandez-Franzon, M.; Berardinis, F.D.; Font, G.; Vittori, S.; Manes, J. Simultaneous determination of eight underivatised biogenic amines in fish by solid phase extraction and liquid chromatography-tandem mass spectrometry, Food Chem. 2012,132, 537-543; DOI: 10.1016/j.foodchem.2011.10.054. 
17. Cohen G.; Rudnik, D.D.; Laloush, M.; Yakir, D.; Karpas, Z. A Novel method for determination of histamine in tuna fish by ion mobility spectrometry, Food Anal. Methods 2015, 8, 2376-2382, DOI: 10.1007/s12161-0150129-3.

18. Draisci, R.; Volpe, P.G.; Lucentini, O.L.; Cecilia, A.; Federico, R.; Palleschi, G. Determination of biogenic amines with an electrochemical biosensor and its application to salted anchovies, Food Chem. 1998, 62, 225232, DOI: . https://doi.org/10.1016/S0308-8146(97)00167-2.

19. Bilgin, B.; Gençcelep, H. Determination of biogenic amines in fish products, Food Sci. Biotechnol. 2015, 24, 1907-1913, DOI: 10.1007/s10068-015-0251-4.

20. Hernandez-Jover, T.; Izquierdo-Pulido, M.; Veciana-Nogués, M.T.; Vidal-Carou M.C. Ion-pair highperformance liquid chromatographic determination of biogenic amines in meat and meat products, J. Agric. Food Chem. 1996, 44, 2710-2715, DOI: 10.1021/jf9506803.

21. Saccani, G.; Tanzi, E.; Pastore, P.; Cavalli, S.; Rey M. Determination of biogenic amines in fresh and processed meat by suppressed ion chromatography-mass spectrometry using a cation-exchange column, $J$. Chromatogr. A 2005,1082, 43-50; DOI: 10.1016/j.chroma.2005.05.030.

22. Stojanovi, Z.S.; Svarc-Gaji, J.V. A simple and rapid method for histamine determination in fermented sausages by mediated chronopotentiometry, Food Contr 2011, 22, 2013-2019, DOI: 10.1016/j.foodcont.2011.05.022.

23. Liu, M.; Li Y.G.; Chou, G.X.; Cheng, X.M.; Zhang, M.; Wang, Z.T. Extraction and ultra-performance liquid chromatography of hydrophilic and lipophilic bioactive components in a Chinese herb Radix Salviae Miltiorrhizae, J. Chromatogr. A 2007,1157, 51-55; DOI: 10.1016/j.chroma.2007.05.018.

24. Moret, S.; Smela, D.; Populin, T.; Conte L.S. A survey on free biogenic amine content of fresh and preserved vegetables, Food Chem 2005, 89, 355-361, DOI: 10.1016/j.foodchem.2004.02.050.

25. Pastore, P.; Favaro, G.; Badacco, D.; Tapparo, A.; Cavalli, C.; Saccani, G. Determination of biogenic amines in chocolate by ion chromatographic separation and pulsed integrated amperometric detection with implemented wave-form at $\mathrm{Au}$ disposable electrode, J. Chromatogr. A 2005, 1098, 111-115, DOI: 10.1016/j.chroma.2005.08.065.

26. Pena-Gallego, A.; Hernndez-Orte, P.; Cacho, J.; Ferreira, V. Biogenic amine determination in wines using solid-phase extraction: a comparative study, J. Chromatogr. A 2009, 1216, 3398-3401, DOI: 10.1016/j.chroma.2009.01.106.

27. Beneduce, L.; Romano, A.; Capozzi, V.; Lucas, P.; Barnavon, L.; Bach, B.; Vuchot, F.; Grieco, G.; Spano, E. Biogenic amine in wines, Ann. Microbiol. 2010, 60, 573-578, DOI: 10.1007/s13213-010-0094-4.

28. Pena-Gallego, A.; Hernandez-Orte, P.; Cacho, J.; Ferreira, A.V. High-Performance Liquid Chromatography Analysis of Amines in Must and Wine: A Review, Food Rev. Int. 2012, 28, 71-96, DOI: 10.1080/87559129.2011.594973.

29. Daniel, D.; dos Santos, V.B.; Vidal, D.T.R.; do Lago, C.L. Determination of biogenic amines in beer and wine by capillary electrophoresis-tandem mass spectrometry, J. Chromatogr. A 2015, 1416, 121-128, DOI: 10.1016/j.chroma.2015.08.065.

30. Tuberoso, C.I.G.; Congiu, F.; Serreli, G.; Mameli, S. Determination of dansylated amino acids and biogenic amines in Cannonau and Vermentino wines by HPLC-FLD, Food Chem. 2015, 175, 29-35.

31. Huang, K.-L.; Jin, C.-X.; Song, S.-L.; Wei, C.-Y.; Liu, Y.-M.; Li, J. Development of an ionic liquid-based ultrasonic-assisted liquid-liquid microextraction method for sensitive determination of biogenic amines: application to the analysis of octopamine, tyramine and phenethylamine in beer samples, J. Chromatogr. B 2011, 879, 579-584, DOI: 10.1016/j.jchromb.2011.01.018.

32. Stratton, J.E.; Hutkins.; R.W.; Taylor.; S.L. Biogenic amines in cheese and other fermented foods: A review. J. Food Prot. 1991, 54, 460-470; DOI: 10.4315/0362-028X-54.6.460.

33. Rak, L. Biogenic amines in dairy products, Med. Weter. 2005, 61, 391-393.

34. EFSA Panel on Biological Hazards (BIOHAZ). Scientific opinion on risk based control of biogenic amine formation in fermented foods. EFSA J. 2011, 9, 2393, DOI: 10.2903/j.efsa.2011.2393.

35. Linares, D.M.; Del Río, B.; Ladero, V.; Martinez, N.; Fernandez, M.; Martín, M.C.; Álvarez, M.A. Factors influencing biogenic amines accumulation in dairy products. Front. Microbiol. 2012, 3, 180, DOI: 10.3389/fmicb.2012.00180.

36. Bonczar, G.; Filipczak-Fiutak, M.; Pluta-Kubica, A.; Duda. I. Biogenic amines present in cheese - occurrence and threats. Med. Weter. 2017, 73, 136-143, DOI: 10.21521/mw.5657. 
37. Novella-Rodríguez, S.; Veciana-Nogués, M.T.; Roig-Sagués, A.X.; Trujillo-Mesa, A.J.; Vidal-Carou, M.C. Influence of starter and nonstarter on the formation of biogenic amine in goat cheese during ripening. J. Dairy Sci. 2002, 85, 2471-2478, DOI: 10.3168/jds.S0022-0302(02)74329-4.

38. Fernández, M.; Linares, D.M.; del Rio, B.; Ladero, V.; Álvarez, M.A. HPLC quantification of biogenic amines in cheeses: correlation with PCR-detection of tyramine-producing microorganisms. J. Dairy Res. 2007, 74, 276-282, DOI: 10.1017/S0022029907002488.

39. Naila, A.; Flint, S.; Fletcher, G.; Bremer, P.; Meerdink, G. Control of biogenic amines in food-existing and emerging approaches. J. Food Sci. 2010, 75, 139-150, DOI: 10.1111/j.1750-3841.2010.01774.x.

40. Innocente, N.; D'Agostin. P. Formation of Biogenic Amines in a Typical Semihard Italian Cheese. J. Food Prot. 2002, 65, 1498-1501, DOI: 10.4315/0362-028X-65.9.1498.

41. Gardini, F.; Martuscelli, M.; Caruso, M.C.; Galgano, F.; Crudele, M.A.; Favati, F.; Guerzoni, M.E.; Suzzi, G. Effect of $\mathrm{pH}$, temperature and $\mathrm{NaCl}$ concentration on the growth kinetic, proteolytic activity and biogenic amines production of Enterococcus faecalis. Int. J. Food Microbiol. 2001, 64, 105-117, DOI: 10.1016/S01681605(00)00445-1.

42. Fernández-García, E.; Tomillo, E.J.; Nuñez, M. Formation of biogenic amines in raw milk Hispanico cheese manufactured with proteinases and different levels of starter culture. J. Food Prot. 2000, 63, 1551-1555, DOI: 10.4315/0362-028X-63.11.1551.

43. Bunková, L.; Bunka, F; Mantlová, G.; Cablová, A.; Sedlácek, I.; Švec, P.; Pachlová, V.; Krácmar, S. The effect of ripening and storage conditions on the distribution of tyramine, putrescine and cadaverine in Edamcheese. Food Microbiol. 2010, 27, 880-888, DOI: 10.1016/j.fm.2010.04.014.

44. Custódio, F.B.; Tavares, E.; Glória, M.B. Extraction of bioactive amines from grated Parmesan cheese using acid, alkaline and organic solvents. J. Food Composit. Anal. 2007, 20, 280-288, DOI: 10.1016/j.jfca.2006.06.009.

45. Ladero, V.; Fernández, M.; Álvarez, M.A. Effect of post-ripening processing on the histamine and histamine-producing bacteria contents of different cheeses. Int. Dairy J. 2009, 19, 759-762, DOI: 10.1016/j.idairyj.2009.05.010.

46. Fernández, M.; Linares, D.M.; Rodríguez, A.; Álvarez, M.A. Factors affecting tyramine production in Enterococcus durans IPLA655. Appl. Microbiol. Biotechnol. 2007, 73, 1400-1406, DOI: 10.1007/s00253-0060596-y.

47. Mayer, H.K.; Fiechter, G.; Fischer, E. A new ultra-pressure liquid chromatography method for the determination of biogenic amines in cheese. J. Chromatogr. A 2010, 1217, 3251-3257, DOI: 10.1016/j.chroma.2009.09.027.

48. Pinho, O.; Ferreira, I.M.; Mendes, E.; Oliveira, B.M.; Ferreira, M. Effect of temperature on evolution of free amino acid and biogenic amine contents during storage of Azeitão cheese. Food Chem. 2001, 75, 287-291, DOI: 10.1016/S0308-8146(01)00109-1.

49. Mercogliano, R.; De Felice, A.; Chirollo, C.; Cortesi, M.L. Production of vasoactive amines during the ripening of Pecorino Carmasciano cheese. Vet. Res. Commun. 2010, 34, S175-S178, DOI: 10.1007/s11259-0109394-1.

50. Schirone, M.; Tofalo, R.; Mazzone, G.; Corsetti, A.; Suzzi, G. Biogenic amine content and microbiological profile of Pecorino di Farindola cheese. Food Microbiol. 2011, 28, 128-136, DOI: 10.1016/j.fm.2010.09.005.

51. Novella-Rodríguez, S.; Veciana-Nogués, M.T.; Izquerdo-Pulido, M.; Vidal-Carou, M.C. Distribution of biogenic amines and polyamines in cheese. J. Food Sci. 2003, 68, 750-755, DOI: 10.1111/j.13652621.2003.tb08236.x.

52. Rabie, M.A.; Elsaidy, S.; el-Badawy, A.A.; Siliha, H.; Malcata, F. X. Biogenic amine contents in selected Egyptian fermented foods as determined by ion-exchange chromatography. J. Food Prot. 2011, 74, 681-685, DOI: 10.4315/0362-028X.JFP-10-257.

53. Erim, F.B. Recent analytical approaches to the analysis of biogenic amines in food samples. Trends Anal.Chem 2013, 52, 239-247; DOI: 10.1016/j.trac.2013.05.018.

54. Papageorgiou, M.; Lambropoulou, D.; Morrison, C.; Kłodzińska, E.; Namieśnik, J.; Płotka-Wasylka, J. Literature update of analytical methods for biogenic amines determination in food and beverages. Trends Anal.Chem 2018, 98, 128-142, DOI: 10.1016/j.trac.2017.11.001.

55. Moret, S.; Conte, L.S. High-performance liquid chromatographic evaluation of biogenic amines in foods an analysis of different methods of sample preparation in relation to food characteristics. J. Chromatogr. A 1996, 729, 363-369, DOI: 10.1016/0021-9673(95)00961-2. 
56. Dadáková, E.; Kř́̌žek, M.; Pelikánová, T. Determination of biogenic amines in foods using ultraperformance liquid chromatography (UPLC). Food Chem. 2009, 116, 365-370; DOI: 10.1016/j.foodchem.2009.02.018.

57. Jia, S.; Kang, Y.P.; Park, J.H.; Lee, J.; Kwon, S.W. Simultaneous determination of 23 amino acids and 7 biogenic amines in fermented food samples by liquid chromatography/quadrupole time-of-flight mass spectrometry. J. Chromatogr. A 2011, 1218, 9174-9182, DOI: 10.1016/j.chroma.2011.

58. Gianotti, V.; Chiuminatto, U.; Mazzucco, E.; Gosetti, F.; Bottaro, M.; Frascarolo, P.; Gennaro, M.C. A new hydrophilic interaction liquid chromatography tandem mass spectrometry method for the simultaneous determination of seven biogenic amines in cheese. J. Chromatogr. A 2008, 1185, 296-300; DOI: 10.1016/j.chroma.2008.02.038.

59. Palermo, C.; Muscarella, M.; Nardiello, D.; Iammarino, M.; Centonze, D. A multiresidual method based on ion-exchange chromatography with conductivity detection for the determination of biogenic amines in food and beverages. Anal. Bioanal. Chem. 2013, 405, 1015-1023, DOI: 10.1007/s00216-012-6439-z.

60. Draisci, R.; Giannetti, L.; Boria, P.; Lucentini, L.; Palleschi, L.; Cavalli, S. Improved ion chromatographyintegrated pulsed amperometric detection method for the evaluation of biogenic amines in food of vegetable or animal origin and in fermented foods. J. Chromatogr. A 1998, 798, 109-116, DOI: 10.1016/S00219673(97)01198-9.

61. Ali Awan, M.; Fleet, I.; Paul Thomas, C.L. Determination of biogenic diamines with a vaporisation derivatisation approach using solid-phase microextraction gas chromatography-mass spectrometry. Food Chem. 2008, 111, 462-468; DOI: 10.1016/j.foodchem.2008.03.068.

62. Aygün, O.; Schneider, E.; Scheuer, R.; Usleber, E.; Gareis, M.; Märtlbauer, E. Comparison of ELISA and HPLC for the determination of histamine in cheese. J. Agric. Food Chem. 1999, 47, 1961-1964, DOI: 10.1021/jf980901f.

63. Numanoğlu, E.; Boyaci, I.H.; Topcu, A. Simple determination of histamine in cheese by capillary electrophoresis with diode array detection. J. Food Drug Anal. 2008, 16, 74-80.

64. Calvo-Pérez, A.; Domínguez-Renedo, O.; Alonso-Lomillo, M.A.; Arcos-Martínez, M.J. Disposable amperometric biosensor for the determination of tyramine using plasma amino oxidase. Microchim. Acta 2013, 180, 253-259, DOI: 10.1007/s00604-012-0926-y.

65. Costa, D.J.E.; Martínez, A.M.; Ribeiro, W.F.; Bichinho, K.M.; Di Nezio, M.S.; Pistonesi, M.F.; Araujo, M.C.U. Determination of Tryptamine in foods using square wave adsorptive stripping voltammetry. Talanta 2016, 154, 134-140, DOI: 10.1016/j.talanta.2016.03.063.

66. Addis, M.; Pirisi, A.; Di Salvo, R.; Podda, F.; Piredda, G. The influence of the enzymatic composition of lamb rennet paste on some properties of experimentally produced PDO Fiore Sardo cheese. Int. Dairy J. 2005, 15, 1271-1278, DOI: 10.1016/j.idairyj.2004.11.012.

67. Pirisi, A.; Pinna, G.; Addis, M.; Piredda, G.; Mauriello, R.; De Pascale, S.; Caira, S.; Mamone, G.; Ferranti, P.; Addeo, F.; Chianese, L. Relationship between the enzymatic composition of lamb rennet paste and proteolytic, lipolytic pattern and texture of PDO Fiore Sardo ovine cheese. Int. Dairy J. 2007, 17, 143-156, DOI: 10.1016/j.idairyj.2006.02.001.

68. Urgeghe, P.P.; Addis, M.; Piga, C.; Scintu, M.F.; Piredda, G.; Sanna, G. Changes in the minority chemical composition during ageing of the traditional PDO Fiore Sardo sheep's cheese. 2018, Submitted.

69. Mannu, L.; Comunian, R.; Scintu, M.F. Mesophilic lactobacilli in Fiore Sardo cheese: PCR-identification and evolution during cheese ripening. Int. Dairy J. 2000, 10, 383-389, DOI: 10.1016/S0958-6946(00)00074-1.

70. Pisano, M.B.; Fadda, M.E.; Deplano, M.; Corda, A.; Cosentino, S. Microbiological and chemical characterization of Fiore Sardo, a traditional Sardinian cheese made from ewe's milk. Int. J. Dairy Technol. 2006, 59, 171-179, DOI: 10.1111/j.1471-0307.2006.00260.x.

71. Mangia, N.P.; Murgia, M.A.; Garau, G.; Sanna, M.G.; Deiana, P. Influence of selected lab cultures on the evolution of free amino acids, free fatty acids and Fiore Sardo cheese microflora during the ripening. Food Microbiol. 2008, 2, 366-377, DOI: 10.1016/j.fm.2007.09.009.

72. Comunian, R.; Paba, A.; Daga, E.; Dupré, I.; Scintu, M.F. Traditional and innovative production methods of Fiore Sardo cheese: a comparison of microflora with a PCR-culture technique. Int. J. Dairy Technol. 2010, 63, 224-233, DOI: 10.1111/j.1471-0307.2010.00581.x.

73. Manca, G.; Porcu, A.; Ru, A.; Salaris, M.; Franco, M.A.; de Santis, E.P.L. Comparison of gammaaminobutyric acid and biogenic amine content of different types of ewe's milk cheese produced in Sardinia, Italy. Ital. J. Food Saf. 2015, 4, 123-128, DOI: 10.4081/ijfs.2015.4700. 
74. Urgeghe, P.P.; Piga, C.; Addis, M.; Di Salvo, R.; Piredda, G.; Scintu, M.F.; Wolf, I.V.; Sanna, G. SPME/GCMS Characterization of the Volatile Fraction of an Italian PDO Sheep Cheese to Prevalent Lypolitic Ripening: the Case of Fiore Sardo. Food Anal. Methods 2012, 5, 723-730, DOI: 10.1007/s12161-011-9302-5.

75. Pulinas, L.; Spanu, C.; Idda, I.; Ibba, I.; Nieddu, G.; Virdis, S.; Scarano, C.; Piras, F.; Spano, N.; Sanna, G.; De Santis, E. P. L. Farmstead production of artisan lactose-free Pecorino di Osilo cheese and Ricotta cheeses from sheep's milk. Ital. J. Food Saf. 2017, 6, 6353, DOI: 10.4081/ijfs.2017.6353.

76. Idda, I.; Spano, N.; Addis, M.; Galistu, G.; Ibba, I.; Nurchi, V.M.; Pilo, M.I.; Scintu, M.F.; Piredda, G.; Sanna G. Optimization of a newly established gas-chromatographic method for determining lactose and galactose traces: Application to Pecorino Romano cheese. J. Food Composit. Anal 2018, 74, 89-94, DOI: 10.1016/j.jfca.2018.09.006.

77. Martuscelli M.; Gardini F.; Torriani S.; Mastrocola D.; Serio A.; Chaves-Lòpez C.; Schirone M.; Suzzi G. Production of biogenic amines during the ripening of Pecorino Abruzzese cheese. Int. Dairy J. 2005, 15, 571578, DOI: 10.1016/j.idairyj.2004.11.008.

78. Mocak, J.; Bond, A.M.; Mitchell S.; Schollary, G. A statistical overview of standard (IUPAC and ACS) and new procedures for determining the limits of detection and quantification: Application to voltammetric and stripping techniques. Pure Appl. Chem. 1997, 69, 297-328, IUPAC recommendation, document 550/35/87. DOI: $10.1351 /$ pac199769020297.

79. Horwitz, W. Evaluation of Analytical Methods Used for Regulation of Foods and Drugs, Anal. Chem. 1982, 54, 67A-76A, DOI: 10.1021/ac00238a765.

80. Torracca, B.; Pedonese, F.; Turchi, B.; Fratini, F.; Nuvoloni, R. Qualitative and quantitative evaluation of biogenic amines in vitro production by bacteria isolated from ewes' milk cheeses. Eur Food Res Technol. 2018, 244, 721-728, DOI 10.1007/s00217-017-2992-1.

81. Moret S.; Bortolomeazzi R.; Lercker G. Improvement of extraction procedure for biogenic amines in foods and their high-performance liquid chromatographic determination. J. Chromatogr. A 1992, 591, 175-180, DOI: 10.1016/0021-9673(92)80235-M.

82. Valsamaki K.; Michaelidou A.; Polychroniadou A. Biogenic amine production in Feta cheese. Food Chem. 2000, 71, 259-266, DOI: 10.1016/S0308-8146(00)00168-0.

83. Gaya, P.; Sánchez, C.; Nuñez M.; Fernández-García E. Proteolysis during ripening of Manchego cheese made from raw or pasteurized ewes' milk. Seasonal variation. J Dairy Res. 2005, 72, 287-95, DOI: $10.1017 /$ S0022029905001019.

84. Contreras, M.; Izquierdo, P.; Allara, M.; García, A.; Torres, G.; Céspedes, E. Determinación de aminas biógenas en quesos madurados. Rev. Cient. FCV-LUZ 2007, 17, 89-95.

85. Poveda, J.M.; Chicón, R.; Cabezas, L. Biogenic amine content and proteolysis in Manchego cheese manufactured with Lactobacillus paracasei subsp. paracasei as adjunct and other autochthonous strains as starters. Int. Dairy J. 2015, 47, 94-101, DOI: 10.1016/j.idairyj.2015.03.004

86. Lanciotti R.; Patrignani F.; Iucci L.; Guerzoni M. E.; Suzzi G.; Belletti N.; Gardini F. Effects of milk high pressure homogenization on biogenic amine accumulation during ripening of ovine and bovine Italian cheeses. Food Chem. 2007,104, 693-701, DOI: 10.1016/j.foodchem.2006.12.017.

87. Pintado, A.I.E.; Pinho, O.; Ferreira, I.M.P.L.V.O.; Pintado, M.M.E.; Gomes, A.M.P.; Malcata F.X, Microbiological, biochemical and biogenic amine profiles of Terrincho cheese manufactured in several dairy farms. Int Dairy J 2008, 18, 631-640, DOI: 10.1016/j.idairyj.2007.11.021.

88. Mascaro, N.; Stocchi, R.; Ricciutelli, M.; Cammertoni, N.; Renzi, F.; Cecchini, S.; Loschi, A.R.; Rea, S. Biogenic amine content and chemical and physical features of italian formaggio di Fossa. Ital. J. Food Safety 2010, 8, 49-53, DOI: 10.4081/ijfs.2010.1037.

89. Buňková, L.; Adamcová, G.; Hudcová, K.; Velichová, H.; Pachlová, V.; Lorencová, E.; Buňka F. Monitoring of biogenic amines in cheeses manufactured at small-scale farms and in fermented dairy products in the Czech Republic. Food Chem. 2013, 141, 548-51, DOI: 10.1016/j.foodchem.2013.03.036.

90. Calzada, J.; Del Olmo, A.; Picon, A.; Gaya, P.; Nuñez, M. Proteolysis and biogenic amine buildup in highpressure treated ovine milk blue-veined cheese. J Dairy Sci. 2013, 96, 4816-4829, DOI: 10.3168/jds.2012-6409.

91. Schirone, M.; Tofalo, R.; Fasoli, G.; Perpetuini, G.; Corsetti, A.; Manetta, A.C.; Ciarrocchi, A.; Suzzi, G. High content of biogenic amines in Pecorino cheeses. Food Microbiol. 2013, 34, 137-144. DOI: 10.1016/j.fm.2012.11.022. 
92. Torracca, B.; Nuvoloni, R.; Ducci, M.; Bacci, C.; Pedonese, F. Biogenic Amines Content of Four Types of "Pecorino" Cheese Manufactured in Tuscany, Int. J. Food Prop. 2015, 18, 999-1005, DOI: 10.1080/10942912.2013.877026.

93. Pirisi A.; Comunian R.; Urgeghe P.P.; Scintu M.F. Sheep's and goat's dairy products in Italy: technological, chemical, microbiological, and sensory aspects. Small Rumin. Res. 2011, 101, 102-112, DOI: 10.1016/j.smallrumres.2011.09.030.

94. Halász S.; Bárath A.; Simon-Sarkadi L.; Holzapfel W. Biogenic amines and their production by microorganism in food. Trend Food Sci. Technol. 1994, 5, 42-49, DOI: 10.1016/0924-2244(94)90070-1.

95. Schirone, M.; Tofalo, R.; Visciano, P.; Corsetti, A.; Suzzi, G. Biogenic Amines in Italian Pecorino Cheese. Front Microbiol. 2012, 3, 171, DOI: 10.3389/fmicb.2012.00171 